\title{
SUOMESSA VILJELLYN PERUNAN VIRUSTAUTISUUDESTA
}

\author{
Klaus Aura \\ Kasvitautien tutkimuslaitos, Tikkurila
}

Saapunut 12. 3. 1957

Kasvitautien tutkimuslaitoksella ryhdyttiin v. 1955 prof. E. A. JAMALAISEN aloitteesta tutkimaan serologisesti perunan S- ja X-viruksien yleisyyttä ja levinneisyyttä maassamme sekä niiden esiintymistä eri perunalajikkeissa. Kasvukautena 1955 suoritti näitä tutkimuksia Kasvitautien tutkimuslaitokselle kerätyistä lehtinäytteistä maassamme työskennellyt virustutkija, insinööri A. B. R. BEFMSTER Hollannista. Hän analysoi serologisesti 550 perunayksilöä, joista $450 \mathrm{kpl}$ oli peräisin eri koepaikoista ja loput $100 \mathrm{kpl}$ maanviljelijöiden pelloilta.

Kasvukaudella 1956 jatkettiin perunan S- ja X-virusten serologisia määrityksiä. Lisäksi tehtiin runsaasti silmävaraisia havaintoja muista perunan virooseista symptomien perusteella. Serologisesti analysoitiin 650 perunayksilöä, joista puolet oli peräisin eri koepaikoista ja puolet yksityisiltä viljelyksiltä, yhteensä 79 kunnan alueelta.

Serologisia määrityksiä varten aineisto kerättiin viljelyksiltä ja koeruuduilta tutkittavia yksilöitä valikoimatta, silloin kun kasvustot näyttivät yhtenäisiltä. Sen sijaan, kun kasvustoissa oli havaittavissa epäyhtenäisyyttä, valittiin analysoitavat kasviyksilöt siten, että ne mahdollisimman hyvin edustivat koko viljelystä tai koeruutua. Lisäksi tehtiin merkintöjä muista perunan virooseista. Perunayksilöistä, joissa ilmeni kurttu- ja viirusymptomeja, otettiin näytteitä, joista serologisesti tutkittiin S- ja X-virusten esiintymistä. Näiden määritysten tarkoituksena oli selvittää, missä määrin nämä virukset ovat maassamme tavattavan kurttuviroosin aiheuttajia.

Kerätyt näytteet säilytettiin muovipusseissa ja serologinen analysointi suoritettiin viimeistään kolmen päivän kuluttua näytteiden oton jälkeen Kasvitautien tutkimuslaitoksella Tikkurilassa ja eräillä koeasemilla.

Serologiset tutkimukset suoritettiin agglutinaatiomenetelmällä (16). Tarvittavat anti- ja normaaliseerumit saatiin Hollannista (Laboratorium voor Bloembollenonderzoek).

Taulukossa 1 on esitetty perunan S- ja X-virusten esiintyminen eri osissa maata vuosina $1955-56$ serologisten määritysten mukaisesti. Taulukosta ilmenee, että S- ja X-virukset ovat sangen yleisiä koko perunanviljelyalueellamme. Eri koeasemien ja yksityisten viljelijöiden peruna-aineistojen välillä ei ollut havaitta- 
Taulukko 1. S- ja X-virusten esiintyminen eri osissa maata v. $1955-56$ suoritettujen serologisten määritysten mukaan.

Table 1. Virus $S$ and virus $X$ in different parts of Finland according to serological determinations in $1955-56$.

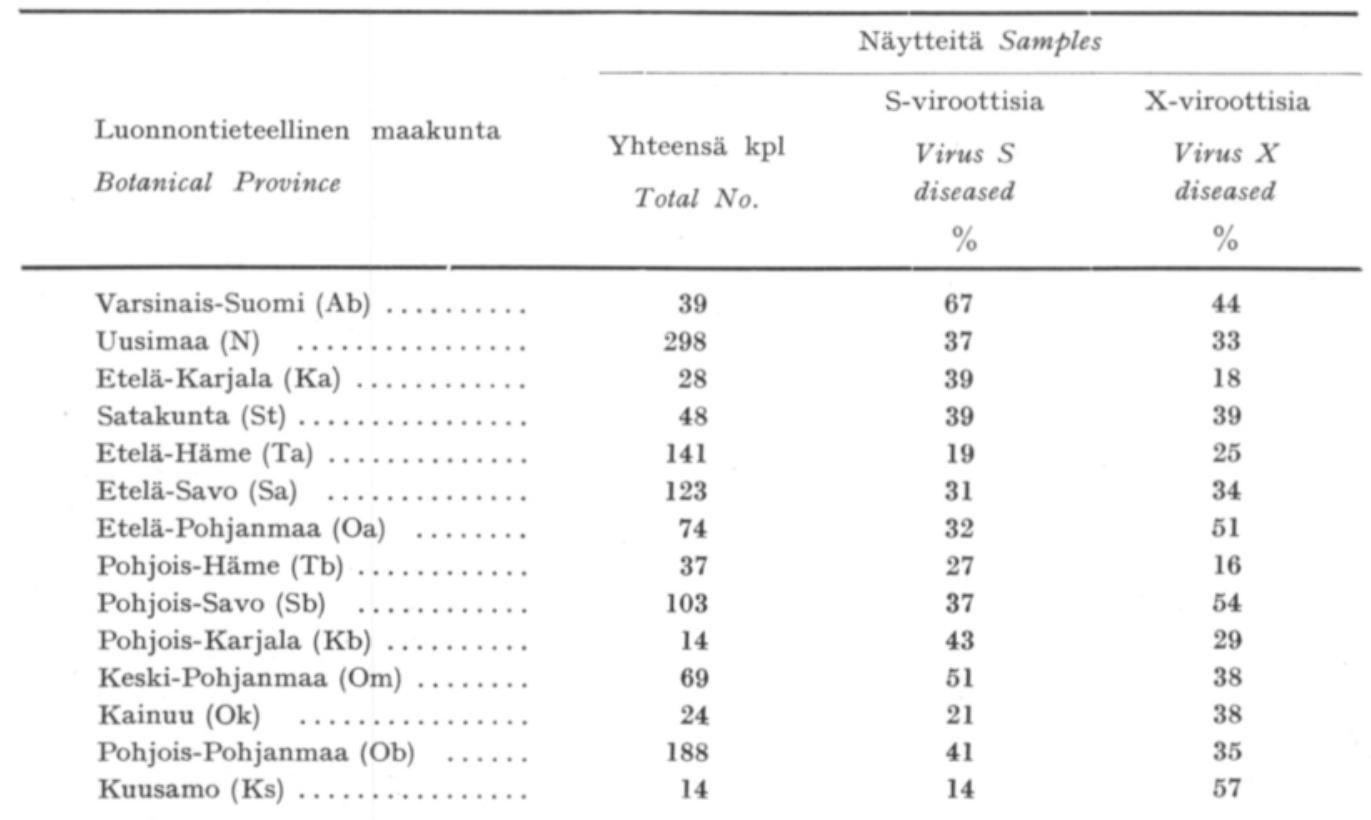

vissa sanottavia viroottisuuseroja, jonka takia niitä ei taulukossa 1 ole erikseen selostettu. Kasvinjalostuslaitoksella Jokioisissa (Ta), jossa tutkittiin kaikkiaan 110 perunayksilöä, esiintyi kuitenkin tavallista vähemmän virustauteja, nähtävästi sen vuoksi, että siellä pyritään mahdollisimman tarkasti poistamaan kokeista kaikki virustautiset perunayksilöt.

Taulukossa 1 esitettyjen tietojen mukaan voi helposti muodostua se käsitys, että S-virus olisi maassamme jonkin verran X-virusta yleisempi. Todellisuudessa tilanne lienee kuitenkin päinvastainen. Tutkitussa materiaalissa oli nimittäin varsin paljon S-viroottiseksi osoittautunutta Jaakko-perunaa, jonka viljelyala maassamme on verraten vähäinen. Sen sijaan meillä ylivoimaisesti eniten viljelty perunalajike Eigenheimer (18) on hyvin X-viroottinen (taulukko 2).

Perun a n S-viru s (13) on ollut tunnettu vasta muutaman vuoden ajan. Se on kuitenkin monissa Euroopan maissa ja Pohjois-Amerikassa laajalle levinnyt $(1,10,11,12,13,15)$. Lisäksi tunnetaan useita S-virukselle lähisukuisia viruksia $(7,8,17)$. Tässä tutkimuksessa tarkoitetaan S-viruksella perunassa esiintyvää antigeeniä, joka reagoi Hollannissa S-virusta vastaan valmistetun antiseerumin kanssa.

S-viruksen aiheuttamat symptomit ovat yleensä lieviä, mutta saattavat vaihdella perunalajikkeen, viruskannan ja kasvuolosuhteiden mukaisesti. Sangen usein esiintyy S-virus täysin tai lähes piilevänä. Monesti on kuitenkin havaittavissa lievää ryppyisyyttä perunan lehdissä. Sen sijaan kirjo-oireet, lehtien tuntuva 
Taulukko 2. Eräiden Suomessa viljeltyjen perunalajikkeiden ja -jalosteiden S- ja X-viroottisuus. Määritykset suoritettu serologisesti v. 1955-56.

Table 2. Virus $S$ and virus $X$ in some potato varieties cultivated in Finland. Sereological determinations from leaf samples in 1955-56.

\begin{tabular}{|c|c|c|c|}
\hline \multirow[b]{2}{*}{$\begin{array}{l}\text { Perunalajike tai jaloste } \\
\text { Potato variety }\end{array}$} & \multicolumn{3}{|c|}{ Näytteitä Samples } \\
\hline & $\begin{array}{c}\text { Yhteensä kpl } \\
\text { Total No. }\end{array}$ & $\begin{array}{c}\text { S-viroottisia } \\
\text { Virus } S \\
\text { diseased } \\
\%\end{array}$ & $\begin{array}{c}\text { X-viroottisia } \\
\text { Virus } X \\
\text { diseased } \\
\%\end{array}$ \\
\hline Akvila (Aquila)..$\ldots \ldots \ldots \ldots \ldots$ & 36 & 22 & 12 \\
\hline Alfa (Alpha) ................. & 33 & 10 & 67 \\
\hline Ben Lomond................ & 11 & 55 & 46 \\
\hline Bintje $\ldots \ldots \ldots \ldots \ldots \ldots \ldots \ldots$ & 24 & 8 & 33 \\
\hline Eigenheimer.$\ldots \ldots \ldots \ldots \ldots \ldots$ & 95 & 31 & 70 \\
\hline Hettula, maatiaisperuna Kittilästä & 22 & 68 & 73 \\
\hline Jaakko ................... & 152 & 71 & 17 \\
\hline Kuningas Yrjö (King Georg) .. & 28 & 14 & 43 \\
\hline Laivaperuna (Odenwälder Blaue) & 23 & 4 & 35 \\
\hline Magnum Bonum..$\ldots \ldots \ldots \ldots$ & 20 & 5 & 40 \\
\hline Muurmannilainen............ & 12 & 25 & 17 \\
\hline Nuutti (Frühnudel) $\quad \ldots \ldots \ldots \ldots$ & 42 & 67 & 26 \\
\hline Olympia $\ldots \ldots \ldots \ldots \ldots . . . .$. & 33 & 61 & 79 \\
\hline Ostbote $\quad \ldots \ldots \ldots \ldots \ldots \ldots$ & 38 & 37 & 34 \\
\hline Paulin peruna (Paul Wagner).... & 19 & 32 & 47 \\
\hline Peippo $\ldots \ldots \ldots \ldots \ldots \ldots \ldots \ldots$ & 17 & 65 & 59 \\
\hline Pepo $\ldots \ldots \ldots \ldots \ldots \ldots \ldots \ldots$ & 20 & 25 & 75 \\
\hline Record $\ldots \ldots \ldots \ldots \ldots \ldots \ldots$ & 19 & 11 & 11 \\
\hline Ruusulehti (Rosafolia) $\ldots . . .$. & 86 & 38 & 58 \\
\hline Sientje $\ldots \ldots \ldots \ldots \ldots \ldots \ldots$ & 46 & 44 & 20 \\
\hline Siikli (Sieglinde) $\ldots \ldots \ldots \ldots \ldots$ & 47 & 13 & 9 \\
\hline Ulster Chieftain $\ldots \ldots \ldots \ldots \ldots$ & 10 & 0 & 0 \\
\hline Upto (Uptodate) $\quad \ldots \ldots \ldots \ldots . .$. & 21 & 14 & 57 \\
\hline Vesijärvi (Harbinger) .......... & 26 & 81 & 12 \\
\hline Zaailing $\quad \ldots \ldots \ldots \ldots \ldots \ldots$ & 20 & 0 & 0 \\
\hline Jo $086 \ldots \ldots \ldots \ldots \ldots \ldots$ & 20 & 10 & 15 \\
\hline Jo $095 \ldots \ldots \ldots \ldots \ldots \ldots$ & 22 & 41 & 14 \\
\hline Та $01783 \ldots \ldots \ldots \ldots \ldots \ldots$ & 32 & 16 & 3 \\
\hline Sekalaiset ja tuntemattomat $\ldots$ & 71 & 20 & 59 \\
\hline
\end{tabular}

kurttuisuus ja muut epämuodostumat ovat harvinaisempia $(14,15)$. Vaikka tauti silmävaraisesti tarkasteltuna näyttää lievältä, voi se, Sveitsissä suoritettujen tutkimusten mukaan (12), aiheuttaa Bintje-lajikkeessa jopa $10-20 \%$ suuruisia sadon alennuksia.

S-virus tarttuu X-viruksen tapaan mekaanisesti kasvimehun välityksellä kasvista toiseen. Tautia levittäviä hyönteisiä ei tunneta. Tämä selittää osaltaan S- ja $\mathrm{X}$-virusten jokseenkin tasaisen levinneisyyden maassamme.

X-v i r u s aiheuttaa meillä lehtien kirjavuutta, mutta usein myös lievää kurttuisuutta. Taudin aiheuttamat sadon alennukset ovat Ruotsissa suoritettujen 
tutkimusten mukaan olleet Bintje- ja Eigenheimer-lajikkeilla keskimäärin 13-20\% (4). Monessa tapauksessa saattaa X-virus esiintyä perunassa myös täysin latenttina.

$\mathrm{X}$-virus lienee yleisin maassamme tavattavista perunan viruksista. Se on levinnyt käytännöllisesti katsoen koko perunanviljelyalueellemme. X-viruksen täysin saastuttamia viljelyksiä on maassamme sangen paljon. Sama koskee myös S-virusta. Lähes kaikki tutkitut viljelykset olivat ainakin osittain saastuneet jompaan kumpaan tai molempiin edellämainituista viruksista. Tutkituista 105:stä viljelyksestä oli vain $10 \%$ sellaisia, joissa ei todettu serologisesti eikä silmävaraisten havaintojen perusteella virussaastuntaa. Mainittakoon, että S- ja X-virukset näyttivät esiintyvän tutkituissa kasveissa täysin toisistaan riippumatta.

$\mathrm{Kurttuviroosiksi}$ nimitetty tauti voi olla monen viruksen aiheuttama. Sekä X- että A-virus saattavat kumpikin olla syynä lievään kurttuviroosiin (9). Lisäksi voi myös S-virus aiheuttaa tietyissä lajikkeissa lehtien kurttuisuutta. Usein on kurttuviroosin syynä myös sekainfektio. X-viruksen ja A-viruksen aiheuttama sekainfektio on monessa maassa kurttuviroosin yleisin syy (9). Tällöin ilmenee kasvissa sangen huomattavaa lehtien kurttuisuutta ja kasvun heikentymistä. Pahin tautimuoto aiheutuu viruskombinaatiosta $\mathrm{X}+\mathrm{Y}$; tällöin ilmenee usein viiruviroosille tyypillisiä nekroosijuovia.

Serologisissa määrityksissä vuonna 1956 todettiin, että 45:stä analysoidusta kurttuviroottisesta kasvista oli n. $90 \%$ sellaisia, joissa oli X-virusta. 20:ssa kasvissa todettiin lisäksi S-virus. Osa maassamme tavattavasta kurttuviroosista saattaa olla sekainfektio A + X:n aiheuttamaa. A-virusta ei meillä tosin ole määritetty, mutta se on mm. naapurimaassamme Ruotsissa sangen yleinen (5).

Maassamme tavattava kurttuviroosi on tehtyjen havaintojen mukaan suurimmaksi osaksi lievää tai lievähköä. Sekainfektio $\mathrm{X}+\mathrm{Y}$ :n aiheuttamana pidettävää ankaraa kurttuviroosia esiintyy sen sijaan vähän, enimmäkseen vain yksittäisinä tapauksina Etelä-Suomessa. Lievät ja lievähköt kurttuviroosimuodot ovat sangen yleisiä maamme etelä- ja lounaisosissa sekä Etelä-Pohjanmaan rannikkoalueella.

Tietoja siitä, miten paljon maassamme esiintyvä kurttuviroosi yleensä alentaa perunasatoja, ei ole käytettävissä. BRUMmeriin suorittamien yksilötutkimuksien mukaan alensi lievä kurttuviroosi satoa $22 \%$ :lla ja taudin vaikeampi muoto $64 \%:$ :lla (2).

Y-viruksen aiheuttamaa vi i ruviroosia, joka määritettiin symptomien perusteella, on meillä tavattu melkein yksinomaan eteläosissa maata. Viiruviroosin levinneisyys maassamme liittynee tautia levittävien kirvojen esiintymiseen. Yviruksen täysin saastuttamia viljelyksiä ei havaintoja tehtäessä todettu. Pahimminkin saastuneilla perunaviljelyksillä oli vain $5-15 \%$ kasveista Y-viroottisia.

Viiruviroosin aiheuttamat sadon alennukset ovat sangen suuria silloin kun tautia esiintyy runsaasti. Suorittamissaan tutkimuksissa on BRUMMER todennut mukuloissa kulkeutuvan, ns. sekundäärisen viiruviroosin vähentävän mukulasatoa jopa $93 \%$ :lla. Sen sijaan Vesijärvi-perunassa esiintyvä sekundäärisenä nekroosittomana viiruviroosina pidetty tauti oli vaikutukseltaan lievempää, sadon alennukset olivat keskimäärin 67 \% (2). Primäärisen, saman kasvukauden aikana saadun infektion aiheuttamat tappiot olivat sen sijaan vähäpätöisiä (3). 
K i erreviroosilla lienee maassamme vain vähäinen merkitys, kuten JAMALAINEN (6) jo aikaisemmin on todennut. Varsin runsaasti esiintyi kierreviroosia kuitenkin vuonna 1956 eräillä koeasemilla, tosin pääasiassa vain ulkoa tuoduissa, todennäköisesti jo maahan saapuessaan saastuneissa Dore- ja Saskia-lajikkeissa (vrt. 6).

Taulukossa 2 on esitetty yhteenvedon muodossa vuosina $1955-56$ suoritettujen serologisten määritysten tuloksia lajikkeittain. Ne lajikkeet, joista saatiin useita näytteitä eri puolilta maata, osoittautuivat yleensä serologisten tutkimusten mukaan likipitäen yhtä viroottisiksi kautta koko maan.

Monien lajikkeiden osalta on serologisesti tutkittujen näytteiden lukumäärä verraten vähäinen. Eniten tutkituista lajikkeista, Eigenheimerista, Ruusulehdistä ja Jaakosta, ehkä myös Siiklistä ja Nuutista suoritettujen määritysten tulokset riittänevät kuitenkin näiden lajikkeiden viroottisuusvertailun perustaksi.

Jaakko-peruna osoittautui erittäin S-viroottiseksi; X-virusta siinä sen sijaan esiintyi vähemmän. S-virus esiintyi Jaakossa miltei latenttina; kasvien lehdissä todettiin vain lievää kupertumista lehtisuonien välissä.

Eigenheimerissa esiintyi runsaasti X-virusta. Symptomit olivat usein selvästi havaittavissa, joskus taas tauti esiintyi miltei latenttina. Lisäksi siinä oli S-virusta varsin paljon. Samaa voidaan sanoa myös Ruusulehdestä, joka Eigenheimerin jälkeen on eniten viljelty perunalajike maassamme. Tulos on varsin odottamaton sillä Ruusulehteä on pidetty meillä erittäin hyvin virustauteja kestävänä lajikkeena (vrt. 6).

Erityisen viroottisia olivat myös sekalaisten ja tuntemattomien lajikkeiden ryhmään kuuluvat perunat, joiden yhteinen viljelyala maassamme on Eigenheimerinkin viljelyalaa laajempi (18).

Kiintoisaa on niinikään todeta, että yksinomaan Pohjois-Suomessa viljelty Hettulan maatiaisperuna oli S- ja X-virusten pahoin saastuttama. Hettulan perunassa, samoin kuin monissa perunajalosteissa saattoivat sekä S- että X-virus esiintyä yhtäaikaisesti latenttina samassa kasvissa.

Uudemmat maassamme viljellyt lajikkeet, kuten Siikli ja Akvila olivat vähemmän viroottisia. Akvilassa esiintyi kuitenkin Karjalan koeasemalla Anjalassa erittäin runsaasti $\mathrm{X}$-virusta, jonka aiheuttamat kirjosymptomit olivat selvästi nähtävissä.

Eri perunalajikkeiden virustaudinkestävyydestä on meillä aikaisemmin julkaistu tietoja (vrt. 2, 6). Ilmeistä on, etteivät mitkään maassamme yleisesti viljellyistä perunalajikkeista ole riittävän resistenttejä S- ja X-viruksia vastaan, koska $\mathrm{mm}$. erittäin kestävänä pidetyssä Ruusulehti-lajikkeessakin esiintyi serologisten testausten mukaan runsaasti näitä viruksia (vrt. taulukko 2). Sen sijaan monet meillä viljellyt lajikkeet ovat $\mathrm{S}$ - ja $\mathrm{X}$-virusten suhteen enemmän tai vähemmän tolerantteja eli virusta sietäviä, jolloin saastuneissa kasveissa ei lainkaan näy symptomeja tai ne ovat hyvin lieviä.

Ulkomailla suoritettuja tutkimuksia perunalajikkeiden virustaudin kestävyydestä ei meillä voitane sellaisenaan käyttää. Eri lajikkeet voivat, kukin reaktionorminsa mukaisesti, reagoida virusten vaikutuksesta Suomessa toisin kuin siellä, missä ulkomaiset tutkimukset on suoritettu. Lisäksi meillä saattaa esiintyä pato- 
geenisuudeltaan erilaisia viruskantoja, jotka voivat saastuttaa muualla kestäviksi tunnettuja perunalajikkeita.

\section{Yhteenveto}

Vuosina 1955-56 määritettiin Kasvitautien tutkimuslaitoksen toimesta serologisesti 1200 perunayksilön S- ja X-viroottisuus. Tutkittu peruna-aineisto oli kasvanut eri puolilla Suomea.

Määrityksissä todettiin, että perunan S- ja X-virukset ovat sangen yleisiä koko perunaviljelyalueellamme. $\mathrm{X}$-virus näyttää olevan S-virusta jonkin verran yleisempi.

Lisäksi tehtiin silmävaraisia havaintoja perunan virustautien esiintymisestä maassamme. Kurttuviroosi, joka todennäköisesti usein on sekainfektion aiheuttamaa, osoittautui yleiseksi ja vahingolliseksi maan etelä- ja länsiosissa.

Viiruviroosia tavataan meillä verraten vähän. Huomattavaa merkitystä sillä näyttää olevan ainoastaan eräin paikoin etelä-Suomessa.

Kierreviroosin merkitys lienee maassamme vähäpätöinen. Sitä todettiin pääasiassa vain eräissä ulkomailta tuoduissa lajikkeissa, jotka luultavasti jo maahamme saapuessaan ovat olleet kierreviroosin saastuttamia.

Serologisissa määrityksissä ilmeni, että kaikki yleiset perunalajikkeemme ovat enemmän tai vähemmän S- ja X-virusten saastuttamia. Eniten viljellyt lajikkeet, Eigenheimer ja Ruusulehti, olivat huomattavassa määrin S- ja X-viroottisia.

Mikään maassamme yleisesti viljellyistä perunalajikkeista ei osoittautunut serologisten määritysten perusteella riittävässä määrin resistentiksi S- ja X-viruksia vastaan.

KIRJALLISUUTTA.

(1) Bagnall, R. H. \& Bradley, R. H. E. 1955. Note on a virus latent in potato plants. Amer. Pot. Journ. 32: $252-253$.

(2) Brummer, V. 1946. Tutkimuksia tärkeimmistä Tammistossa esiintyneistä perunavirooseista. Hankkijan siemenjulk. 1946: 176-185.

(3) — 1949. Vesijärven ja Tammiston Aikaisen suhtautumisesta perunavirooseihin. Maat.tiet. aikak. 21: 17-28.

(4) Emilsson, B. \& Gustafsson, N. 1956. The influence of potato virus X on yield, tuber size and chemical composition of the tubers. Acta agr. scand. 6: 369-382.

(5) EsBo, H. 1946. Potatisvirosernas utbredning i Sverige. Nord. Jordbr. Forskn. 3 4: $101-109$.

(6) Jamalainen, E. A. 1946. The significance of potato virus diseases in Finland. Maat.tiet. aikak. 18: $134-146$.

(7) Kassanis, B. 1955. Some properties of four viruses isolated from carnation plants. Ann. Appl. Biol. 43: $103-113$.

(8) Köhler, E. 1953. Ein unbekanntes Kartoffelvirus. Ber. der Deut. Bot. Ges. 66: $63-65$.

(9) Köhler, E. \& Klınkowski, M. 1954. Viruskrankheiten. Handbuch der Pflanzenkrankheiten 2, 1: 1-770. Berlin.

(10) Larson, R. H. 1955. Potato virus S-a new problem for the virologist and breeder, a review. Amer. Pot. Journ. 32: 424-425. 
(11) LevieIL, P. 1954. Etude du virus S. Rev. Aval Douar Breiz 27: 9-11.

(12) MÚnster, J. \& Pelet, F. 1954. Le virus S et son influence sur le rendement d'une varieté de pomme de terre. Sta. Fed. d'Essais Agr. Lausanne 452: 931—936.

(13) Rozendaal, A. 1954. De beteknis van verschillene virusgroupen voor de teelt van pootgoed. Landb. voorl. 11: $299-308$.

(14) Rozendal, A. \& Brust, J. H. 1955. The significance of potato virus $\mathrm{S}$ in the seed potato culture. Proc. Conf. Pot. virus dis. 1954, p. 120-133. Lisse-Wageningen.

(15) Rønde Kristensen, H. 1956. Kartoffel virus S. Ugeskr. for Lantm. 101: $323-326$.

(16) Stogteren, E. van. 1952. The serological diagnosis of plant diseases caused by viruses. Rep. of the thirtenth Intern. Hort. Congr. London.

(17) Wetter, C. \& Brandes, G. 1956. Untersuchungen über das Kartoffel S-virus. Phytopath. Z. 26: $81-92$.

(18) YLIMÄKI, A. 1956. Perunaruton torjuntamahdollisuuksista. Käytännön Maamies 6: 38-39.

\section{S U M M A R Y :}

\section{ON POTATO VIRUS DISEA SES IN FINLAND}

Klaus Aura

Department of Plant Pathology, Agricultural Research Centre, Tikkurila

In 1955 the Department of Plant Pathology set to work, on Professor E. A. Jamalainen's iniative, to study serologically the occurrence and distribution of potato viruses $\mathrm{X}$ and $\mathrm{S}$ in Finland and their prevalence in different potato varieties. In 1955 determinations of potato leaf material were made by Mr. A. B. R. BeEMSter of the Institute for Phytopathological Research at Wageningen, Holland, who worked in the Department of Plant Pathology in August-October 1955. He analysed serologically leaves of potato plants, of which $\mathbf{4 5 0}$ samples had been collected from different potato experiments, the rest, 100 samples, coming 'from farmers' fields.

In the period of growth in 1956, the serological determinations were continued, and in addition a great number of visual observations of potato virus diseases were made on the basis of symptoms. A total of 650 potato plants were analysed; one half the plants coming from different potato experiments and the other half from farmers' fields, althogether from 79 communes.

The serological virus determinations were made in accordance with the agglutination method. The needed antisera and normal sera had been received from Holland (Laboratorium voor Bloembollenonderzoek).

Table 1, p. 104 shows the occurrence of virus $\mathrm{S}$ and virus $\mathrm{X}$ in different parts of the country in 1955-56. It appears that viruses $\mathrm{S}$ and $\mathrm{X}$ are rather prevalent in the whole of Finland wherever potato is grown.

According to the data in Table 1 it is possible to conclude that in Finland virus $\mathrm{S}$ would be to some extent more common than virus $\mathrm{X}$. In fact the contrary appears to be true. In the studied material there was a great deal of the Jaakko potato variety, which was heavily infected by virus S. This variety is, indeed, comparatively little cultivated in Finland. Instead, the Eigenheimer variety, which is by far the most commonly cultivated potato in this country (18), is very much infected by virus X (Table 2 , p. 105).

Fields completely infected by virus $\mathrm{X}$ and virus $\mathrm{S}$ are very common in Finland. Nearly all the examined potato fields were at least partly infected either by both of these viruses or by one of them. Only $10 \%$ of the studied 105 fields were without virus infection according to serological determinations and visual observations.

The losses caused by potato Crincle mosaic are, according to observations, mostly slight or moderate in Finland. They are very common in the southern and southwestern parts of Finland and in the coastal 
region of South-Ostrobothnia (West Finland). Information concerning the general losses caused by potato Crincle mosaic in Finland is not available. According to the work of Brummer (2), the slight type of Crinkle mosaic lowered the yields by $22 \%$ and the more severe type by $64 \%$.

Rugose mosaic caused by a combination of $\mathrm{X}$ and $\mathrm{Y}$ viruses occurs mostly in isolated cases in South Finland.

Streak and Rugose caused by virus $\mathrm{Y}$, which was determined on the basis of the symptoms, has been found in Finland only in isolated cases in the southern parts of the country. The spreading of virus Y Rugose in Finland may be connected with the prevalence of the virus spreading aphids. Fields totally infected by virus $\mathrm{Y}$ have not been found. Even in the badly infected potato fields only $5-15 \%$ of the plants proved to be infected with virus $\mathrm{Y}$.

Potato Leaf roll seems of minor significance in Finland as has earlier been established by JAMALAINEN (6). This disease was, however, abundant in 1956 on some Local Experimental Stations, though mainly on the Dore and Saskia potato varieties, which, being imported from abroad, were probably already infected.

Table 2 p. 105 presents a summary of the serologically determined virus $\mathrm{X}$ and virus $\mathrm{S}$ on different potato varieties. Those varieties, of which a number of samples had been received from different parts of the country, proved to be, according to the serological determinations, approximately similarly infected by viruses throughout the country.

The Jaakko potato variety proved very heavily infected by virus S; virus $\mathrm{X}$, on the other hand, was less to be found. Virus S occurred in the Jaakko variety almost latent; the leaves were only slightly convex between the veins.

Virus $\mathrm{X}$ was abundant on the Eigenheimer potato variety. Virus S was also relatively abundant in this variety. The same applies to the Rosafolia potato variety, which is the most cultivated variety in Finland after Eigenheimer.

Varieties belonging to groups of the miscellaneous and unknown potato varieties were also particularly virus infected; the cultivated area of these is even larger than that of Eigenheimer (18).

It was interesting also to establish that the country potato variety Hettula, cultivated only in North Finland, was severely infected by virus $\mathrm{S}$ and virus $\mathrm{X}$. In the Hettula variety, as in many other varieties, viruses $\mathrm{X}$ and $\mathrm{S}$ could be simultaneously latent in the same plant.

The newer potato varieties cultivated in Finland, such as Siikli and Akvila, were only slightly infected by viruses. The Akvila variety was, however, at a Carelian Local Experimental Station, very heavily infected by virus $\mathrm{X}$. 